\title{
Rock analysis to characterize Saudi soft sandstone rock
}

\author{
Omar A. Almisned ${ }^{1} \cdot$ Naif B. Alqahtani ${ }^{2}$ (I) \\ Received: 3 March 2021 / Accepted: 2 April 2021 / Published online: 10 May 2021 \\ (c) The Author(s) 2021
}

\begin{abstract}
As more engineering projects and activities are taking place on and around weak rocks, it is becoming more important to study and characterize them. Since regular practices of rock mechanical testing are not effective for weak rocks, special laboratory tests and measurements were performed to characterize the Alkharj Saudi weak sandstone rock which is a clastic rock dominantly sandy limestone and sandstone. Test results are presented in this paper. Porosity, permeability, and mechanical properties (stress, strain, Poisson's ratio, confined compressive strength and unconfined compressive strength) were obtained and then used to characterize the proposed weak rock. This paper provides a mean of classifying weak soft rocks despite encountered problems in handling and testing such materials.
\end{abstract}

Keywords Weak rock · Soft rock characterization · Rock mechanics · Rock properties · Confined compressive strength · Unconfined compressive strength

\section{Introduction}

Soft rocks are the rock materials that have a strength between soils and hard rocks and do not crumble when immersed in water (Nickmann et al. 2006; Kanji 2014b). They are distinguished from hard rocks by their disintegration and irreversible loss of strength when being exposed to water and climate change within relatively short time. Soils are not classified as rocks and their loss of strength can be reversible (Nickmann et al. 2006) if water is dried. Definition of the range of unconfined compressive strength (UCS) of soft rocks varies among the experts. Terzaghi and Peck (1967) in their study set the lower limit that distinguish soft rocks from soils to a UCS higher than $4000 \mathrm{kN} / \mathrm{m}^{2}$, and Doberiner (1984) uses $5000 \mathrm{kN} / \mathrm{m}^{2} \mathrm{UCS}$ as the lower limit of soft rocks. The upper limit of the strength of soft rocks that distinguish it from hard rocks is $25,000 \mathrm{kN} / \mathrm{m}^{2}$ (Kanji 2014b). According to the International Society for Rock Mechanics

Naif B. Alqahtani nqahtani@kacst.edu.sa

1 National Center for Petroleum Technology and Earth Exploration, King Abdulaziz City for Science and Technology, Riyadh, Kingdom of Saudi Arabia

2 National Center for Carbon Management Technology, King Abdulaziz City for Science and Technology, Riyadh, Kingdom of Saudi Arabia
(ISRM), the USC range of $250-25,000 \mathrm{kN} / \mathrm{m}^{2}$ represents extremely weak to weak rocks (ISRM 1981). Although coming across soft rocks in engineering projects are increasing, soft rocks characterization and mechanical testing are deficient in both information and confidence (Fernandes 2018). Consequently, this deficiency leads to higher cost due to higher precautious safety factors. The purpose of soft rocks characterization is to anticipate the rock expected behavior under different stresses (Kanji 2014b). There are many criteria in the literature to distinguish between soft rocks and hard rocks, and to distinguish between soft rocks and soils.

He and Kanji (2014) highlighted the importance of soft rocks laboratory studies and case experience reporting. Also, growing soft rock encountering in engineering activities was emphasized in their studies. The fact that soft rocks are difficult to sample as well as to test causes fewer studies (Kanji 2014b). Some of the general soft rock characteristics are: (a) low UCS, (b) facility to crumble, disaggregate, and/or be weathered, (c) high plasticity (Kanji 2014a). It is important to study and characterize weak rocks and develop a specific classification system for soft rocks.

Characterizing soft rocks physical and mechanical properties help in preventing and/or minimizing potential challenges in engineering applications associated with weak formations. One of the main properties of a porous media is the storage capacity, porosity $(\phi) \%$. Additionally, it is very important to determine the connectivity of these pores and 
the porous media ability to conduct fluids that is absolute permeability $(\mathrm{K})$ and its unit is $\left(\mathrm{m}^{2}\right)$, when fully saturated with one fluid. Many difficulties were encountered when testing weak rock core samples, some of these were reported in a previous publication (Almisned et al. 2011). In this paper, characterizing and classifying of Alkharj soft rocks is presented despite the encountered difficulties in handling and testing this soft rock.

\section{Literature review}

Several types of soft rock characterization have been reported in the literature (Terzaghi and Peck 1967; Dobereiner 1984; Huang et al. 2000, 2020 Blumel 2005; Nickmann et al. 2006; He 2014; Kanji 2014a, b; Zhou et al. 2014; Wang et al. 2020). There have been many efforts to collect and study all data published since 1976 for the purpose of providing a practical utilization of the collected data to present some correlations based on the physical and rock mechanical properties such as rock type, porosity, density, cementation degree to predict soft rock behavior (Kanji 2014b). To show the importance of soft rock mechanical properties and characterization and behavior prediction, Kanji (2014b) presented the cases of a dam foundation, a slope, and an underground opening.

Kanji (2014a) discussed some of the critical issues with soft rocks including the factors influencing the rock strength and distinguishing between soft rocks and soils. He attempts to develop an index property correlation that can be used to classify the rock's strength such as density, porosity, and absorption correlations. Also, he emphasized the need to develop a geomechanical classification criteria for soft rocks.

$\mathrm{He}$ (2014) listed many projects in China where soft rock supporting technologies were applied. The technologies included theories, concepts, materials, and design methods. The paper showed that Chinese scholars suggest the use of strength index in defining soft rocks rather than the uniaxial compressive strength (UCS).

The soft rock material can be classified if it has a UCS below $20,000 \mathrm{kN} / \mathrm{m}^{2}$, determined directly by uniaxial compression tests (Bieniawski 1989; Franklin and Dusseault 1989; Bell 1994). However, Huang et al. (2000) conducted a study to improve the capability to characterize the engineering properties of soft rocks with a UCS less than 10,000 $\mathrm{kN} / \mathrm{m}^{2}$ in Taiwan. They suggested an improved core barrel to be used in soft rock formations, and proposed a modified laboratory procedure and interpretation of laboratory and field results. Zhou et al. (2014) conducted a laboratory study on the chlorite schist soft rocks crossing the deep-buried tunnel section of a hydropower station in China. In addition to the petrophysical and mechanical properties of a soft rock, they investigated water-weakening of soft rocks and suggested reinforcement methods. They concluded that the water's effect on soft rocks develops a reduction in strength and an increase in deformation which makes necessary an appropriate confining pressure to mitigate the water-weakening effect. Nickmann et al. (2006) studied 40 different rock types. In their paper, they showed the wetting-drying cycle where diagenesis and metamorphism drive one direction and weathering drives towards the opposite direction.

They suggested the classification of rock types based on a new testing method that observes the rock's behavior and includes several factors such as pore volume, grain size distribution, compressive strength and not only one parameter. They called these groups of parameters structural strength. Blumel (2005) conducted a laboratory study to investigate the mechanical characterization complexity on weak rocks. The author concluded that they are affected by sampling method, the common heterogeneity and anisotropy of the weak rocks and testing method. The challenges in soft rock laboratory testing call for a sophisticated testing procedures to ensure good results. A good example of soft rocks encounter with engineering projects is tunnel instability.

Huang et al. (2020) investigated the instability of a shallow tunnel in soft rocks by constructing a physical model representing the field case and tested it in the laboratory. They also developed a numerical model for the case. When results of the laboratory testing of the physical model were compared with numerical analysis, they showed a good match describing the failure which took place at the top (tunnel crown) then at the walls of the tunnel. While encountering soft rocks represent a challenge for most engineering projects, there are some useful utilizations of soft rocks.

A positive utilization of soft rocks to improve the physical properties of sandy soils was shown by Wang et al. (2020), where soft rocks were added to sandy soils to increase the bulk density and reduce the porosity, and consequently reducing the moisture content of the sandy soils. It is clearly and repeatedly emphasized in the literature that engineering projects and activities are increasingly encountering weakrock's areas. Also, if a rock does not meet a characterization criterion used to indicate and/or classify soft rocks, it does not exclude the possibility of meeting another approaches(s) to characterize soft rocks. This paper shows a case of overcoming difficulties to characterize a soft rock.

\section{Material and method}

\section{Sample collected}

Chunks of rocks were collected from area outcrops (Fig. 1), south of Riyadh, central Saudi Arabia. Figure 2 shows the outcrops that rock samples were collected from. Figure 3 shows the outcrop site of the soft rocks cucountered in 


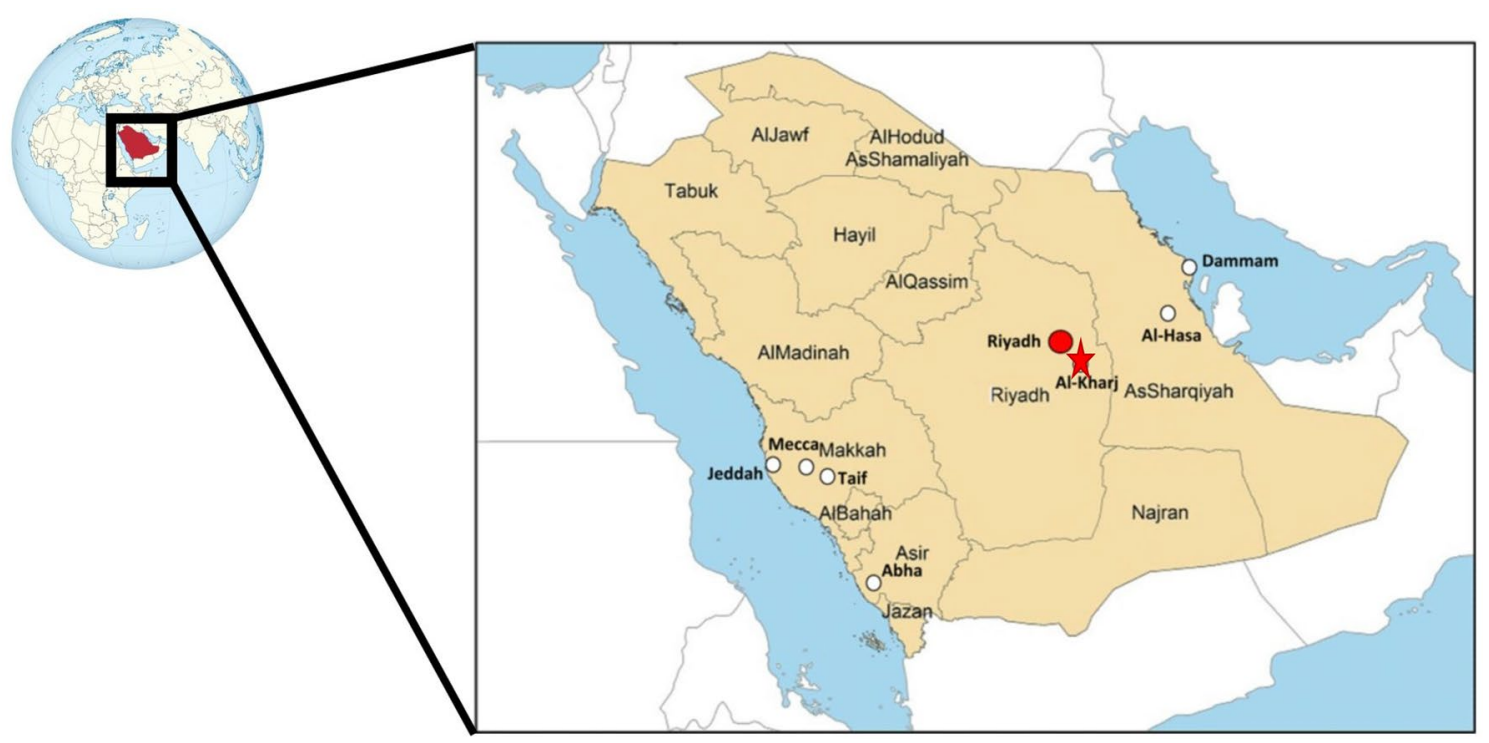

Fig. 1 A map showing the location of the outcrops located south of Riyadh

Fig. 2 The outcrop of collected samples

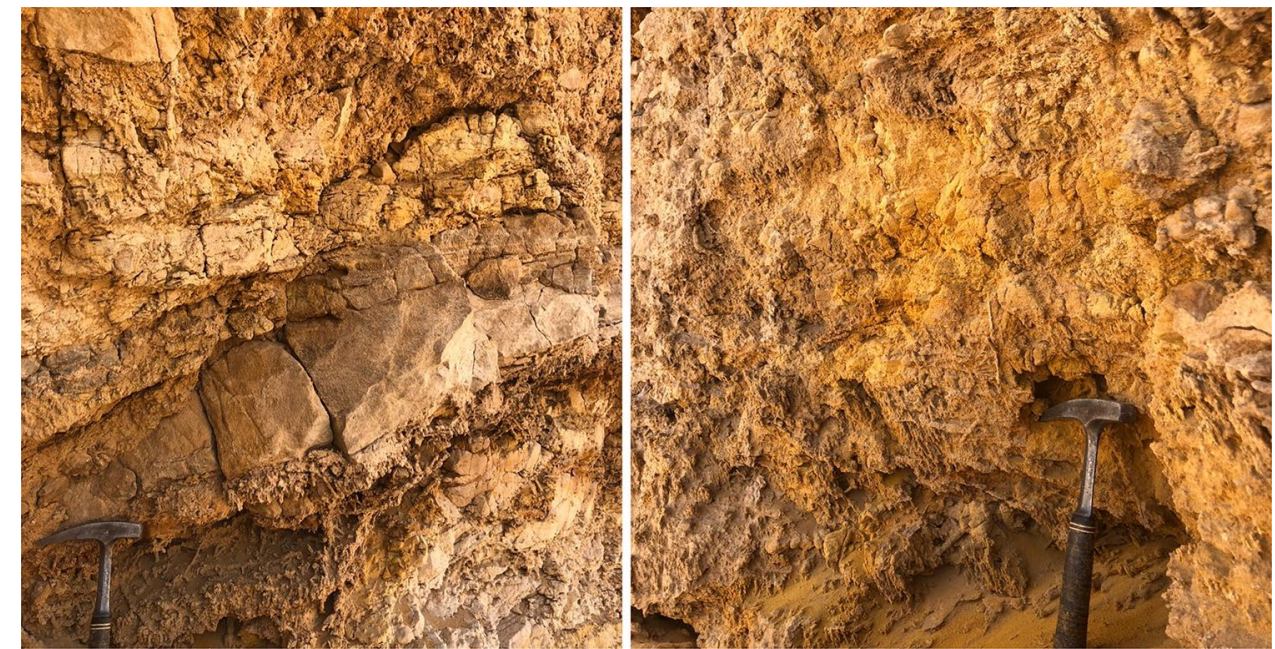

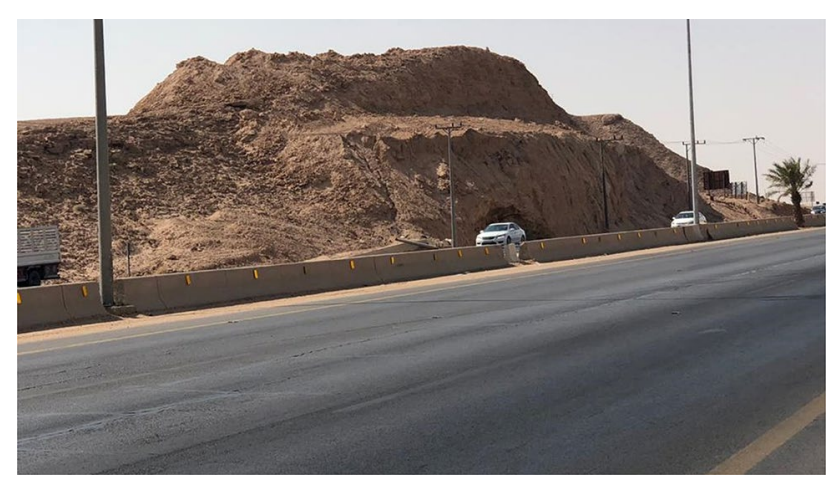

Fig. 3 Outcrop site showing soft rocks cucountered in engineering projects engineering projects. The formation is young and the rock is weak. Regular cylindrical shape samples were cored and prepared for testing. The diameter of each core sample is $0.0381 \mathrm{~m}$ and the length is $0.0762 \mathrm{~m}$. The mineral composition in this rock sandstone type was 91\% Quartz, 5\% Hematite and $2.9 \%$ Kaolinite clay. It is yellowish in color and composed of rounded grains.

\section{Experimental method}

A core flooding unit was used for permeability measurements in this study. The core sample was tested sequentially by placing the core in the Hoek cell and loading with and 


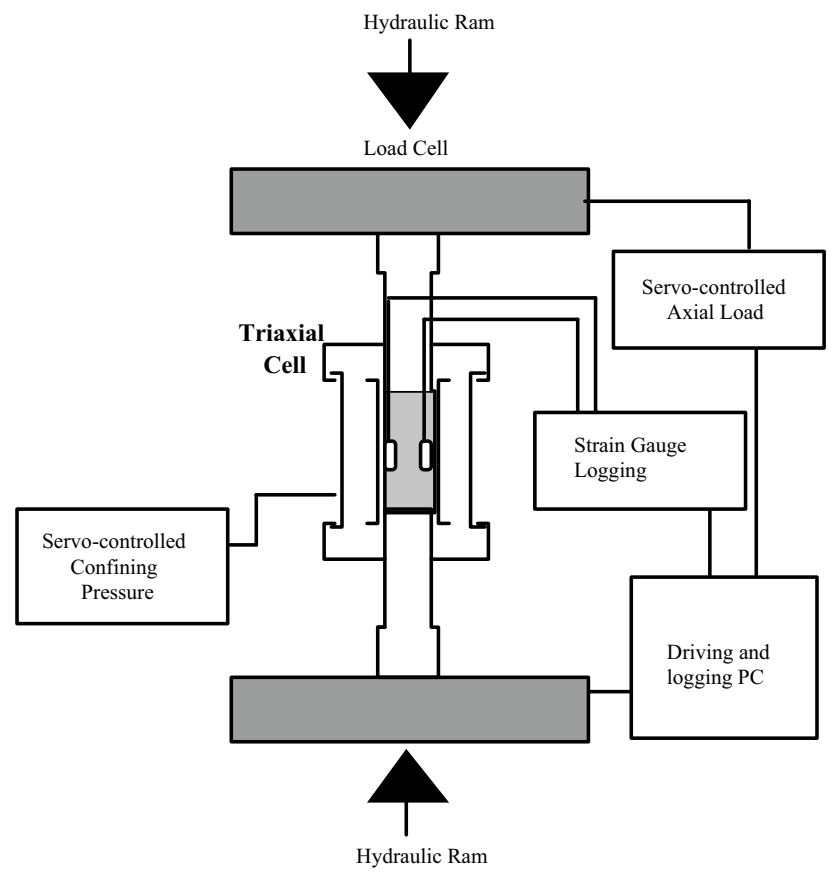

without confining pressure around the sides of the core. Figure 4 shows a schematic of the testing setup used in this study. The permeability measurements and porosity values used in this study to help classifying the type of rocks and to prove if it is in the range of the soft weak rock as illustrated in Fig. 5. From Zoback (2010), the unconfined compressive strength (UCS) can be calculated using Eq. (1) if the confined compressive strength (CCS) is known along with the sandstone internal angle of friction $(\varnothing)$ and the confining pressure:

$\mathrm{UCS}=\mathrm{CCS}-P \tan ^{2}\left(45+\frac{\emptyset}{2}\right)$

where CCS $=$ confined compressive strength $\left(\mathrm{kN} / \mathrm{m}^{2}\right)$, $\mathrm{UCS}=$ unconfined compressive strength $\left(\mathrm{kN} / \mathrm{m}^{2}\right), \mathrm{P}=$ confining pressure $\left(\mathrm{kN} / \mathrm{m}^{2}\right), \varnothing=$ Internal angle of friction (degree).

Fig. 4 Schematic of the triaxial testing setup (Edimann et al. 1998)

Fig. 5 Permeability/porosity plot showing newly deposited beach sands and three sample suites from wells in oil and gas fields. Permeability scale ranges from $10 \mathrm{e}^{-10} \mathrm{~m}^{2}$ to $10 \mathrm{e}^{-20} \mathrm{~m}^{2}$. (after PetroWiki 2013)

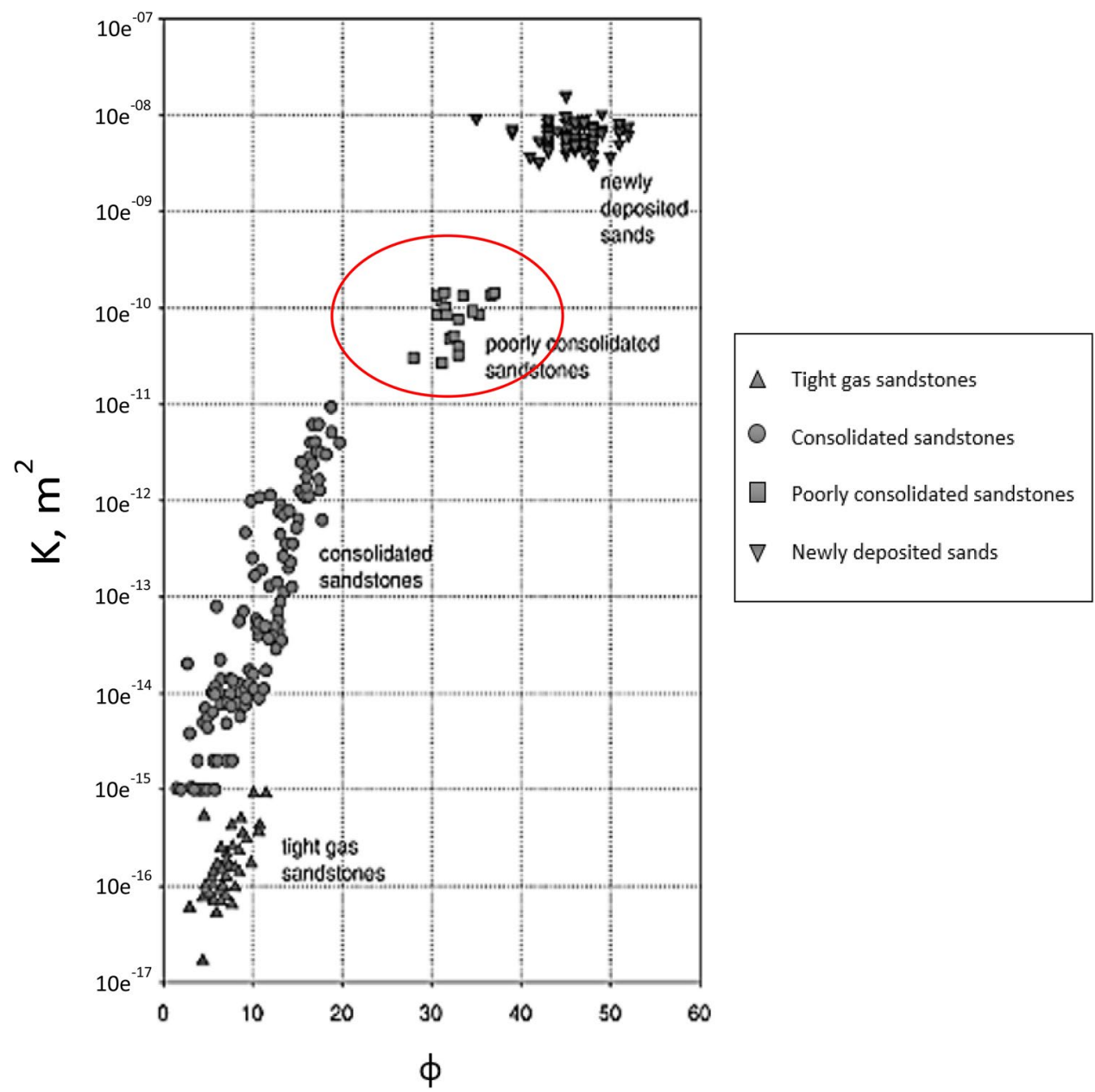




\section{Results and discussion}

The tested rock is found to be weathered, highly disintegrating sandstone weak rocks; however, when core samples were immersed in water, they stayed intact (the type and amount of bonding materials are good enough to keep the rock intact). The porosities of the core samples were found to be in the range of $35 \%$.

Table 1 shows the absolute permeability measurements and calculations using a core flooding unit. Those permeability values show more reasonable values comparing with results for same sample using a gas permeameter where unrealistic permeability values, over $10 \mathrm{e}^{-12} \mathrm{~m}^{2}$, were obtained (Almisned et al. 2011). The absolute permeability value is around $1.2 \mathrm{e}^{-12} \mathrm{~m}^{2}$, which is reasonable for such shallow weak sandstone formation rocks. The porosity and permeability data of this sample indicate that the sample is poorly consolidated sandstone as illustrated in the permeability/porosity plot (Fig. 5).

Table 1 Absolute permeability (K) measurements of soft rocks using core-flooding unit

\begin{tabular}{lllll}
\hline Run \# & $\begin{array}{l}\sigma_{1} \\
\mathrm{kN} / \mathrm{m}^{2}\end{array}$ & $\begin{array}{l}\sigma_{3} \\
\mathrm{kN} / \mathrm{m}^{2}\end{array}$ & $\begin{array}{l}\sigma_{\mathrm{AVG}} \\
\mathrm{kN} / \mathrm{m}^{2}\end{array}$ & $\begin{array}{l}k \\
\mathrm{~m}^{2}\end{array}$ \\
\hline 1 & 3092 & 6911 & 5541 & $1.2 \mathrm{e}^{-12}$ \\
2 & 3084 & 6905 & 5525 & $1.2 \mathrm{e}^{-12}$ \\
3 & 3084 & 6911 & 5536 & $1.2 \mathrm{e}^{-12}$ \\
4 & 3064 & 6905 & 5571 & $1.2 \mathrm{e}^{-12}$ \\
\hline
\end{tabular}

Figure 6 shows results of stress versus strain measurements during confined compressive test. The stress-strain curve shows that the sandstone sample's yield point is at $3385 \mathrm{kN} / \mathrm{m}^{2}$. However, the sample was fully crushed at higher stress value $\left(\sim 3778 \mathrm{kN} / \mathrm{m}^{2}\right)$ after two of uncomplete deformation cycles because the sample was under confining stress which kept the rock sample held intact during the loading and prevented it from collapsing. In other words, when the rock started to fail, the confining pressure was increased resulting in an uncompleted failure. This was repeated at a higher stress and another uncompleted failure was obtained (see Fig. 5). The UCS value is $972 \mathrm{kN} / \mathrm{m}^{2}$. According to Santana et al. (2014), the soft rock has low UCS values comparing to moderate and hard rocks, which are between 1000 and $5000 \mathrm{kN} /$ $\mathrm{m}^{2}$. Also, according to National Engineering Handbook (2012), the classification of soft rock is an UCS falling in the range from 1250 to $5000 \mathrm{kN} / \mathrm{m}^{2}$. Hence, the tested sandstone rock samples in this study are falling in the soft rock category.

The Poisson's ratio versus strain in the range between 0.32 and 0.45 , this high Poisson's ratio value indicates that the sample is a soft sandstone type of rock according to Chopra and Castagna (2014). Where most consolidated rocks are under 0.33 , while poorly consolidated or soft rock has higher Poisson's ratio value that could reach 0.5.

Figure 7 a shows a disintegrated core sample when tested at $0.0 \mathrm{kN} / \mathrm{m}^{2}$ confining pressure, while Fig. $7 \mathrm{~b}$ shows a compacted core sample after a test with increasing confining pressure.
Fig. 6 Stress versus strain curve for the soft sandstone sample

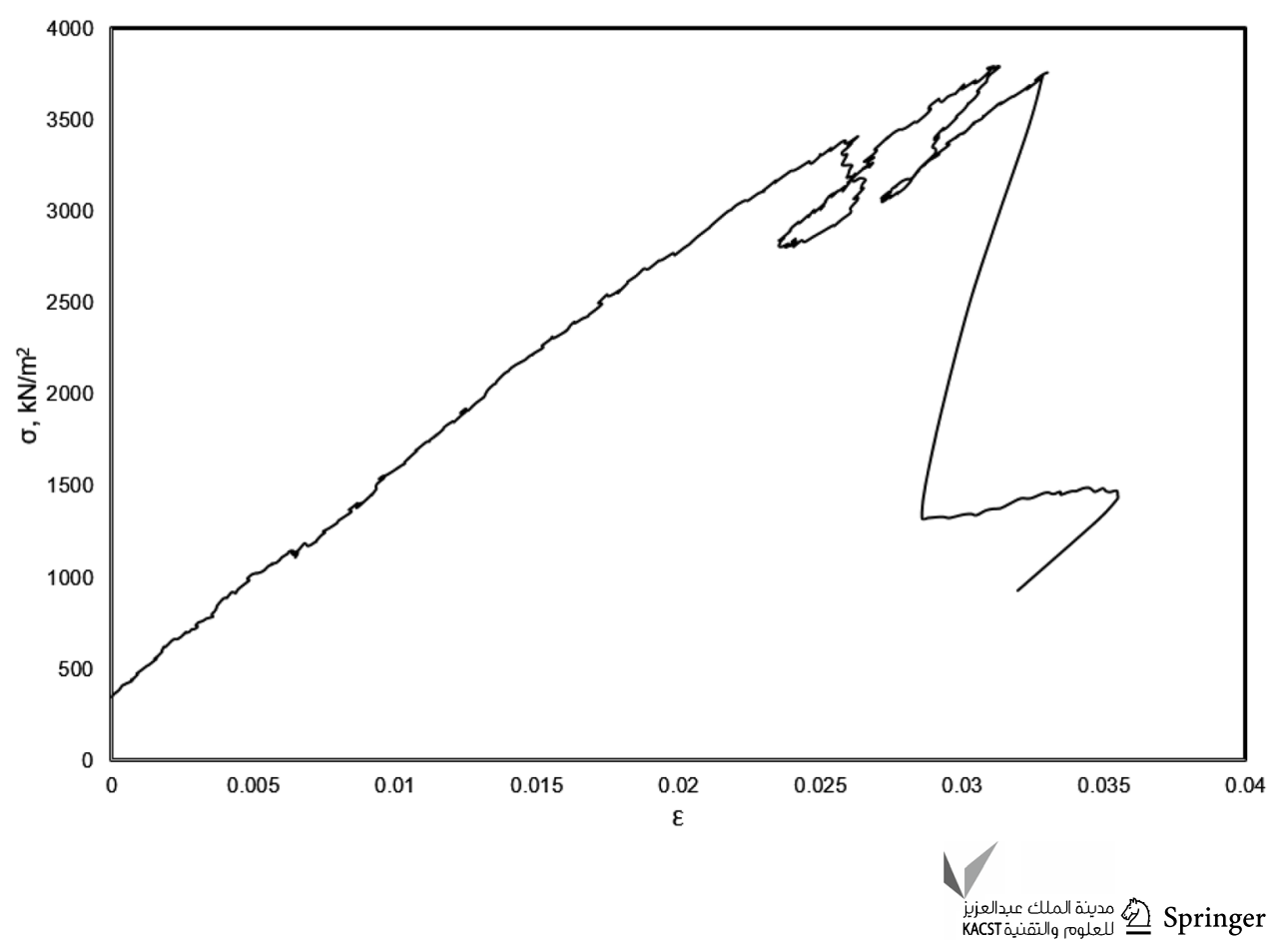


Fig. 7 a Disintegrated core sample tested at $0.0 \mathrm{kN} / \mathrm{m}^{2}$ confining pressure, while $\mathbf{b}$ is a compacted core sample of weak rock tested with increasing confining pressure

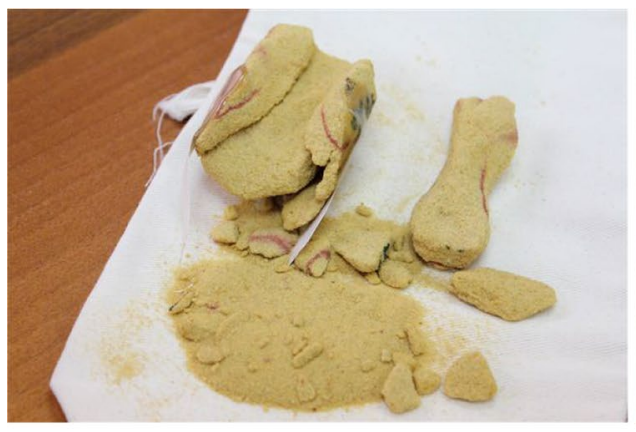

(a)

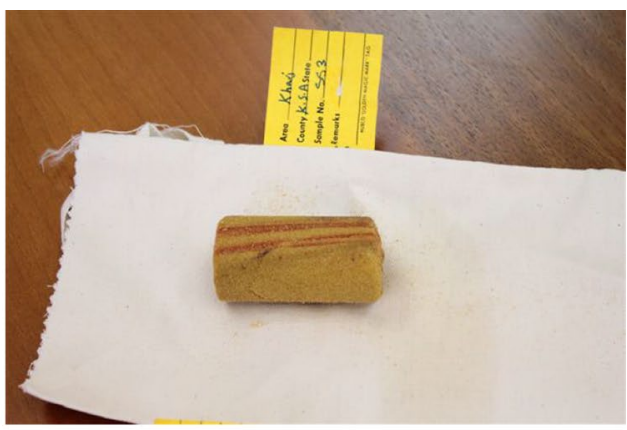

(b)

\section{Conclusion}

Regular practices of rock mechanical testing might not be effective for soft rocks. Different equipment, practices, and/ or protocol must be adapted for soft rock category. The pace of studying soft rocks needs to catch up with soft rock's encountering engineering projects and utilization in soft rock's area. In this study, weak shallow young sandstone rocks from Alkharj area outcrop, central province, Saudi Arabia were collected, tested, and characterized despite the difficulties in handling and testing weak rocks. Based on the petro-physical and rock mechanical results, the tested weak shallow rock can be classified and characterized using many applications that are used in other practices, such as the petroleum-engineering applications. Alkharj soft rocks considered to be categorized as a soft rock (UCS value of $972 \mathrm{kN} / \mathrm{m}^{2}$ and the Poisson's ratio is between 0.32 and 0.45 ) since it has a high Poisson's ratio value and low UCS.

Acknowledgements The authors gratefully acknowledge the support by King Abdulaziz City for Science and Technology.

\section{Declaration}

Conflict of interest The authors wish to confirm that there are no known conflicts of interest associated with this publication and there has been no significant financial support for this work that could have influenced its outcome.

Open Access This article is licensed under a Creative Commons Attribution 4.0 International License, which permits use, sharing, adaptation, distribution and reproduction in any medium or format, as long as you give appropriate credit to the original author(s) and the source, provide a link to the Creative Commons licence, and indicate if changes were made. The images or other third party material in this article are included in the article's Creative Commons licence, unless indicated otherwise in a credit line to the material. If material is not included in the article's Creative Commons licence and your intended use is not permitted by statutory regulation or exceeds the permitted use, you will need to obtain permission directly from the copyright holder. To view a copy of this licence, visit http://creativecommons.org/licenses/by/4.0/.

\section{References}

Almisned OA, Somerville J, Smart BGD (2011) Difficulties in laboratory characterization of weak sandstone. In: 45th US rock mechanics/geomechanics symposium. American Rock Mechanics Association.

Bell FG (1994) Engineering in rock masses. Butterworth-Heinemann, Oxford

Bieniawski ZT (1989) Engineering rock mass classifications. Wiley, New York

Blümel M (2005) Laboratory testing for soft rock-a challenge. In: Impact of human activity on the geological environment EUROCK 2005: proceedings of the international symposium EUROCK 2005, 18-20 May 2005, Brno, Czech Republic. CRC Press, p 57

Chopra S, Castagna JP (2014) Investigations in geophysics-AVO. Society of Exploration Geophysicists, Tulsa

Dobereiner L (1984) Engineering geology of weak sandstone. Ph.D. thesis. University of London

Edimann K, Somerville JM, Smart BGD, Hamilton SA, Crawford BR (1998) Predicting rock mechanical properties from wireline porosities. In: SPE/ISRM rock mechanics in petroleum engineering. Society of Petroleum Engineers.' https://doi.org/10.2118/ 47344-MS

Fernandes Leao M (2018) Characterization of weathered soft rock mass by index tests. Int J Paleobiol Paleontol 1(1):1-6

Franklin JA, Dusseault MB (1989) Rock engineering. McGraw-Hill Publishing Company, New York

He M (2014) Latest progress of soft rock mechanics and engineering in China. J Rock Mech Geotech Eng 6(3):165-179. https://doi.org/ 10.1016/j.jrmge.2014.04.005

He M, Kanji MA (2014) Special issue on science and technology of soft rocks. Int J Min Sci Technol 24(6):725-892

Huang AB, Liao JJ, Pan YW, Cheng MH, Hsieh SY, Peng JK (2000) Characterization of soft rocks in Taiwan. In: 4th North American rock mechanics symposium. American Rock Mechanics Association

Huang F, Wu C, Jang BA, Hong Y, Guo N, Guo W (2020) Instability mechanism of shallow tunnel in soft rock subjected to surcharge loads. Tunn Undergr Space Technol 99:103350. https://doi.org/ 10.1016/j.tust.2020.103350

International Society for Rock Mechanics (ISRM) (1981) Rock characterization testing and monitoring. Pergam on Press, New York, p 211

Kanji MA (2014a) Critical issues in soft rocks. J Rock Mech Geotech Eng 6(3):186-195. https://doi.org/10.1016/j.jrmge.2014.04.002

Kanji MA (2014b) Engineering works affected by soft rocks. In: ISRM conference on rock mechanics for natural resources and 
infrastructure-SBMR 2014. International Society for Rock Mechanics and Rock Engineering

National Engineering Handbook, Part 631 Geology, Chapter 4: engineering classification of rock materials. United States Department of Agriculture (USDA), Natural Resources Conservation Service (NRCS) (210-VI-NEH, Amend. 55, January 2012)

Nickmann M, Spaun G, Thuro K (2006) Engineering geological classification of weak rocks. In: Proceedings of the 10th international IAEG congress, vol 492, pp 1-9

PetroWiki (2013) Retrieved in November 24, 2019. http://petrowiki. org/Rock_type_influence_on_permeability

Santana M, Estaire J, Yepes J (2014) Geotechnical characterization of rocky materials from Arteara rock avalanche (Gran Canaria). In: Rock engineering and rock mechanics: structures in and on rock masses-proceedings of EUROCK 2014, ISRM European regional symposium.

Terzaghi K, Peck R (1967) Soil mechanics in engineering practice. Wiley, New York

Wang Y, Ge L, Chendi S, Wang H, Han J, Guo Z, Lu Y (2020) Analysis on hydraulic characteristics of improved sandy soil with soft rock. PLoS ONE 15(1):e0227957. https://doi.org/10.1371/journ al.pone. 0227957

Zhou H, Zhang C, Li Z, Hu D, Hou J (2014) Analysis of mechanical behavior of soft rocks and stability control in deep tunnels. J Rock Mech Geotech Eng 6(3):219-226. https://doi.org/10.1016/j.jrmge. 2014.03.003

Zoback MD (2010) Reservoir geomechanics. Cambridge University Press 